\title{
Evaluation of the effectiveness of leveraging capital of a telecommunication company
}

\author{
Tatyana Martynova ${ }^{1, *}$, Oleslav Antamoshkin ${ }^{1,2}$, Yuriy Danilchenko ${ }^{1}$, Dmitry Eremeev $^{1}$ and Elena Vaitekunene $^{1,2}$ \\ ${ }^{1}$ Reshetnev Siberian State University of Science and Technology, 31, Krasnoyarsky Rabochy Av., 660037 Krasnoyarsk, Russian \\ Federation \\ ${ }^{2}$ Siberian Federal University, 79, Svobodny Av., Krasnoyarsk, 660041, Russian Federation
}

\begin{abstract}
Any company, and especially an actively developing one, constantly feels the need to attract financial resources. Debt capital plays an important role for companies as an additional means for expanding and carrying out economic activities. Accordingly, effective management of borrowed capital is economically beneficial for the company, and the wrong approach to the formation of borrowed sources of the company can adversely affect its financial condition. The object of research in this article was PJSC "MegaFon". A characteristic feature of this industry is the increased competition due to the aggressive policies of both telecom operators and companies that have entered this market from related industries. In the study, the process of forming borrowed funds by the company is presented in the form of five consecutive stages. The approbation of the proposed research scheme, using the example of PJSC "MegaFon", showed the ambiguity of the financial decisions made to attract borrowed capital. And the main recommendation is to attract borrowed funds only for the development of the company.
\end{abstract}

\section{Introduction}

Borrowed capital arises at a certain stage of production development and is conditioned by socio-economic relations, when production reaches a level of development at which the organization does not have enough equity capital to support production and expand it [1-3].

On the other hand, there are quite wealthy members of society and organizations who are willing not only to meet their personal needs, but also to lend their capital for the purpose of productive use. Of course, the lender does not care how his capital is used, it is in his interest to get the surplus value on it in the form of interest, but the borrower can get the surplus value from the borrowed capital received only if it is used productively.

Borrowed capital is a historical concept and, starting from the capitalist stage of historical development, has an objective nature. It is formed under the influence of economic and social factors. Having emerged in the earlier stages of capitalism in the form of loans, loans, and payables, with the development of its borrowed capital also takes the form of commercial creditpromissory notes, the emergence and growth of jointstock companies encourages the emergence of bond loans. Resource provision of the enterprise is a necessary condition for its development. It is the availability of financial resources that determines the possibility of forming debt capital in the company. Leveraged capital is a catalyst for business processes, enabling businesses to increase the company's profit and value [4-6].
The essence of the company's borrowed capital is manifested in the implementation of operational, coordination, control and regulatory functions of the process of attracting external sources of financing. The company's management system must respond promptly to changes in internal and external factors, namely, changes in borrowing conditions, changes in borrowing methods, and the emergence of new ways to attract borrowed sources of financing.

Borrowed capital as a financial category expresses economic relations inherent only to it, mediated by a certain amount of funds transferred for temporary use by one economic entity to another. In this capacity, the borrowed capital represents the unity of the economic relationship and its form (monetary, tangible or intangible).

The use of borrowed capital to finance the company's activities has certain advantages. Borrowed capital has a wide range of opportunities to attract (with a high credit rating of the borrower), and with the help of financing from debt sources, it is possible to avoid attracting an additional number of shareholders and founders.

Accordingly, effective management of borrowed capital is economically beneficial for the company, and the wrong approach to the formation of borrowed sources of the company can adversely affect its financial condition [7-9].

\section{Materials and Methods}

\footnotetext{
* Corresponding author: ies_vel@mail.ru
} 
Sources and instruments of debt financing are quite diverse. But it should be noted that the attraction of borrowed capital is based on the fundamental principles that determine its essence: repayment, payment and urgency.

In addition to the general advantages and disadvantages, each leveraged capital instrument may have its own advantages and disadvantages, which are derived from their specifics. In the scientific and educational literature, the following forms of attracting borrowed capital are distinguished: bank loans, bond issues, leasing.

When choosing the forms, methods of attracting debt capital, companies need to conduct a thorough analysis of their activities, as well as the conditions of the financing market, as well as the situation in the economic and financial sector of the country.

Borrowed capital has a wide range of opportunities to attract (with a high credit rating of the borrower), and with the help of financing from debt sources, it is possible to avoid attracting an additional number of shareholders and founders.

Accordingly, effective management of borrowed capital is economically beneficial for the company, and the wrong approach to the formation of borrowed sources of the company can adversely affect its financial condition.

The telecommunications services sector is one of the most important and promising areas of the Russian economy, the development of which is fundamentally necessary for the strategic development of all sectors. The Russian mobile market is represented by four main operators: MegaFon, MTS, VEON (VimpelCom) and Tele2.

PJSC "MegaFon" is an integrated digital communications company that occupies a leading position in the telecommunications market in Russia and the world. The company belongs to the three largest mobile operators in Russia.

"MegaFon" continues to actively expand its portfolio of digital products and services that create real value for customers in all business segments, which contributes to further growth in operational and financial performance and strengthens the company's digital leadership in the market.

Based on the available information [1-3] and the data of the analytical credit agency [6-9], we can say that too much borrowing reduces the financial stability of the enterprise, so the creation of an effective system of debt management is very important and should be based on the organization of planning, formation and use of debt capital.

In general, considering the opinions expressed in the theory and practice of financial management [10-14], I would like to note that the management of borrowing is a purposeful process of their formation from various sources and in different forms in accordance with the needs of the organization at various stages of its development.

The process [12] of forming borrowed funds by the company includes five main stages.

In the first stage, we study the dynamics of total borrowing in the period under review; rate these dynamics are compared with the growth rate of the sum of own financial resources of the volumes of operational and investment activities, the total assets of the organization.

At the second stage, the main forms of borrowing are determined, and the dynamics of the share of formed financial credit, commodity credit, and internal payables in the total amount of borrowed funds used by the company are analyzed.

At the third stage, the ratio of the volume of borrowed funds used by the organization by the period of their attraction is determined. To this end, a corresponding group used borrowed capital, we study the dynamics of the ratio of short- and long-term borrowings of the company and according to the amount of current and non-current assets.

At the fourth stage, the composition of specific creditors of the company and the conditions for their provision of various forms of financial and commodity (commercial) loans are studied.

At the fifth stage, the effectiveness of the use of borrowed funds in general and their individual forms in the organization is studied.

The information base of the study was the data of the open accounting statements according to the standards of IFRS “MegaFon” for a number of years.

\section{Results and Discussion}

Debt capital plays an important role for companies as an additional means for expanding and carrying out economic activities. But since the borrowed capital is raised on the terms of repayment with interest, companies must assess the current circumstances, considering their financial condition, before borrowing money to carry out economic activities.

In addition, the high proportion of borrowed funds, the high level of interest rate for the loan means that the attraction of new borrowed funds is an irrational decision, and it can worsen the financial condition and lead to bankruptcy.

Therefore, it is necessary to conduct systematic monitoring and a thorough analysis of borrowed funds before deciding on their additional attraction.

First of all, we will analyze the structure of the obligations of PJSC MegaFon. The results of the analysis are presented in Tables 1 and 2. 
Table 1. Volumes of the liabilities structure of PJSC "MegaFon", million rubles.

\begin{tabular}{|c|c|c|c|c|}
\hline Commitments & \multicolumn{4}{|c|}{ Years } \\
\cline { 2 - 5 } & 2016 & 2017 & 2018 & 2019 \\
\hline Long-term loans and borrowings & 195724 & 212097 & 288262 & 350066 \\
\hline Other non-current liabilities & 33958 & 47891 & 39741 & 124848 \\
\hline Long-term liabilities & 229682 & 259988 & 328003 & 474914 \\
\hline Short-term loans and borrowings & 39389 & 52013 & 39232 & 25692 \\
\hline Other current liabilities & 64397 & 84417 & 72371 & 87901 \\
\hline Current liabilities & 107978 & 136430 & 111603 & 113593 \\
\hline Total liabilities & 337660 & 396418 & 439606 & 588507 \\
\hline
\end{tabular}

Table 2. Dynamics of the liabilities structure of PJSC "MegaFon", million rubles.

\begin{tabular}{|c|c|c|c|c|c|c|c|}
\hline \multirow{2}{*}{ Commitments } & \multicolumn{3}{|c|}{ Growth rate, \% } & \multicolumn{4}{c|}{ Specific gravity, \% } \\
\cline { 2 - 8 } & $2017 / 2016$ & $2018 / 2017$ & $2019 / 2018$ & 2016 & 2017 & 2018 & 2019 \\
\hline Long-term loans and borrowings & 8.4 & 35.9 & 21.4 & 58.0 & 53.5 & 65.6 & 59.5 \\
\hline Other non-current liabilities & 41.0 & -17.0 & 214.2 & 10.1 & 12.1 & 9.0 & 21.2 \\
\hline Long-term liabilities & 13.2 & 26.2 & 44.8 & 68.0 & 65.6 & 74.6 & 80.7 \\
\hline Short-term loans and borrowings & 32.0 & -24.6 & -34.5 & 11.7 & 13.1 & 8.9 & 4.4 \\
\hline $\begin{array}{c}\text { Other current } \\
\text { liabilities }\end{array}$ & 31.1 & -14.3 & 21.5 & 19.1 & 21.3 & 16.5 & 14.9 \\
\hline Current liabilities & 26.3 & -18.2 & 1.8 & 32.0 & 34.4 & 25.4 & 19.3 \\
\hline Total liabilities & 17.4 & 10.9 & 33.9 & 100 & 100 & 100 & 100 \\
\hline
\end{tabular}

The structure of liabilities shows that PJSC MegaFon uses more long-term liabilities to finance its activities, namely, long-term loans and borrowings.

Let us consider in more detail the structure of borrowed funds of a telecommunications company.

Table 3. Volumes of the borrowed funds structure of PJSC "MegaFon", million rubles.

\begin{tabular}{|c|c|c|c|c|}
\hline \multirow{2}{*}{ Elements of borrowed funds } & \multicolumn{4}{|c|}{ Years } \\
\cline { 2 - 5 } & 2016 & 2017 & 2018 & 2019 \\
\hline Loans in rubles-fixed rates & 12720 & 161928 & 230855 & 236850 \\
& 3 & & & \\
\hline Loans in rubles-floating rates & & & & 38000 \\
\hline Loans in US dollars-floating rates & 38661 & 34153 & 20598 & \\
\hline Loans in US dollars-fixed rates & 7347 & 5082 & 6340 & 71 \\
\hline Loans in euros-floating rates & 8103 & 9171 & 15575 & 14684 \\
\hline Total bank loans & $\begin{array}{c}18131 \\
4\end{array}$ & 210334 & 273368 & 289605 \\
\hline bonds in rubles & 55000 & 55000 & 55000 & 85000 \\
\hline Total long-term borrowings & 23631 & 265334 & 328368 & 374605 \\
& 4 & & & \\
\hline Current portion of long-term loans and \\
borrowings
\end{tabular}

Table 4. Dynamics of the borrowed funds structure of PJSC "MegaFon", million rubles.

\begin{tabular}{|c|c|c|c|c|c|c|c|}
\hline \multirow{2}{*}{ Elements of borrowed funds } & \multicolumn{3}{|c|}{ Growth rate, \% } & \multicolumn{4}{c|}{ Specific gravity, \% } \\
\cline { 2 - 8 } & $2017 / 2016$ & $2018 / 2017$ & $2019 / 2018$ & 2016 & 2017 & 2018 & 2019 \\
\hline Loans in rubles-fixed rates & 27.3 & 42.6 & 2.6 & 53.8 & 61.0 & 70.3 & 63.2 \\
\hline Loans in rubles-floating rates & & & 100.0 & & 0.0 & & 10.1 \\
\hline Loans in US dollars-floating rates & -11.7 & -39.7 & -100.0 & 16.4 & 12.9 & 6.3 & 0.0 \\
\hline Loans in US dollars-fixed rates & -30.8 & 24.8 & -98.9 & 3.1 & 1.9 & 1.9 & 0.02 \\
\hline Loans in euros-floating rates & 13.2 & 69.8 & -5.7 & 3.4 & 3.5 & 4.7 & 3.9 \\
\hline Total bank loans & 16.0 & 30.0 & 5.9 & 76.7 & 79.3 & 83.3 & 77.3 \\
\hline bonds in rubles & 0.0 & 0.0 & 54.5 & 23.3 & 20.7 & 16.7 & 22.7 \\
\hline Total long-term borrowings & 12.3 & 23.8 & 14.1 & 100 & 100 & 100 & 100 \\
\hline $\begin{array}{c}\text { Current portion of long-term loans and } \\
\text { borrowings }\end{array}$ & 29.4 & -25.6 & -37.5 & 16.7 & 19.2 & 11.5 & 6.3 \\
\hline
\end{tabular}

The analysis of the elements of the company's debt capital showed that the structure is dominated by long-
The results of the analysis are presented in Tables 3 and 4 , which show the dynamics of the increase in the company's borrowed funds. 
At the same time, the company began to attract less loans in foreign currency, the share of which in the structure of borrowed capital for the analyzed period decreased from $22.9 \%$ to $12.9 \%$.

It should be noted that in 2019, PJSC "MegaFon" prematurely repaid dollar loans with fixed and floating rates, the payment term for which was originally set for the end of 2021 and 2022.

As the analysis showed, during the analyzed period, the company did not attract short-term loans, loans to finance current activities. Thus, the short-term part of the borrowed capital is represented by long-term loans, the repayment period of which occurs within a year.

The main reason for raising debt capital is related to financing corporate needs, to finance the repurchase of ordinary shares in 2018-2019, as well as to restructure its loan portfolio.

Let us consider in more detail the basic information about the outstanding bonds of PJSC "MegaFon", presented in Table 5.

Table 5. Basic information on outstanding bonds of PJSC "MegaFon".

\begin{tabular}{|c|c|c|c|c|}
\hline Bond Series & Volume, billion rubles & Coupon rate, $\%$ & Maturity date & Number of coupon periods \\
\hline BO-001 R-02 & 10 & 9.9 & 29.05 .2026 & every six months \\
\hline BO-001 R-03 & 15 & 7.85 & 03.10 .2022 & every six months \\
\hline BO-001 R-04 & 20 & 7.2 & 15.02 .2021 & every six months \\
\hline BO-001 R-05 & 20 & 8.55 & 31.01 .2022 & every six months \\
\hline BO-001 R-06 & 5 & 8.9 & 11.03 .2024 & every six months \\
\hline BO-002 R-01 & 5 & 8.9 & 11.03 .2024 & every six months \\
\hline BO-002 R-02 & 10 & 8.9 & 06.04 .2026 & every six months \\
\hline
\end{tabular}

Since the company attracts loans in different currencies with a floating interest rate, it is necessary to determine the LIBOR and EURIBOR rates for the analyzed period, using additional information from the sources. The results of the calculations are presented in Table 6.
The data in Table 6 shows that the cheapest source of financing for the company is foreign currency loans. But attracting foreign currency loans increases the impact of currency risk.

Table 6. Interest rate on borrowed funds of PJSC "MegaFon", \%.

\begin{tabular}{|c|c|c|c|c|}
\hline Elements & \multicolumn{4}{|c|}{ Years } \\
\cline { 2 - 5 } & 2016 & 2017 & 2018 & 2019 \\
\hline Loans in rubles with a fixed rate & 9.6 & 9.6 & 9.3 & 11.13 \\
\hline Loans in rubles with a floating rate & - & - & - & $6.9-7.32$ \\
\hline Loans in US dollars with a floating rate & 4.59 & 2.97 & 2.29 & - \\
\hline Fixed-rate US dollar loans & 2.1 & 2.97 & 2.29 & - \\
\hline Floating-rate Euro loans & 1.96 & 1.81 & 0.94 & 0.28 \\
\hline Bonds in rubles & 9.8 & 8.9 & 8.6 & 8.6 \\
\hline Weighted average interest rate & 8.3 & 8.4 & 8.3 & 9.7 \\
\hline
\end{tabular}

The increase in the weighted average interest rate in 2019 to $9.7 \%$ is due to an increase in the interest rate on ruble-denominated loans with a fixed interest rate. Consequently, in 2019, the company's bonds were the cheapest borrowed capital.

Studying the borrowed funds, you must know the objective laws of the rate of change of the volume of attracted funds and the rate of change in working capital, production and product sales, net profit, etc.

In table 7 we will consider the dynamics of changes in key financial indicators of PJSC "MegaFon".

The results of Table 5 show that for the analyzed period, the excess of the rate of growth of borrowed capital in comparison with the growth of revenue may indicate a decrease in the efficiency of using borrowed funds.

With a decrease in net profit in 2017 and 2019, there is an increase in borrowed funds. At the same time, in 2018 , the growth rate of net profit exceeded the growth rate of borrowed funds by many times.

It should be noted that in 2018, with a net profit growth of $517 \%$, there is an increase in borrowed funds by $23.8 \%$, a decrease in equity by $57.4 \%$, as well as a decrease in the company's assets, which indicates a decrease in the financial stability of "MegaFon". Studying borrowed funds, it is necessary to determine their efficiency of use. 
Table 7. Dynamics of changes in key financial indicators.

\begin{tabular}{|c|c|c|c|c|}
\hline Indicators & \multicolumn{5}{|c|}{ Years } \\
\cline { 2 - 5 } & 2016 & 2017 & 2018 & 2019 \\
\hline Growth rate of liabilities, \% & - & 17.4 & 10.9 & 33.9 \\
\hline Growth rate of borrowed funds, \% & - & 12.3 & 23.8 & 14.1 \\
\hline Growth rate of equity capital, \% & - & 33.2 & -57.4 & 48.6 \\
\hline Growth rate of non-current assets, \% & - & 20.7 & -8.6 & 36.9 \\
\hline Growth rate of current assets, \% & - & 17.0 & -12.2 & 31.3 \\
\hline The growth rate of assets, \% & - & 21.6 & -9.2 & 35.9 \\
\hline Revenue growth rate, \% & - & 1.7 & 4.3 & 4.0 \\
\hline The growth rate of net profit, \% & - & -79.2 & 517.0 & -75.1 \\
\hline
\end{tabular}

In Table 8, we consider the indicators that characterize the effectiveness of the use of borrowed funds of PJSC "MegaFon".

Table 8. Indicators that characterize the effectiveness of the use of borrowed funds of PJSC "MegaFon".

\begin{tabular}{|c|c|c|c|c|}
\hline \multirow{2}{*}{ Indicators } & \multicolumn{4}{|c|}{ Years } \\
\cline { 2 - 5 } & 2016 & 2017 & 2018 & 2019 \\
\hline $\begin{array}{c}\text { The coefficient of concentration of the attracted } \\
\text { capital }\end{array}$ & 0.51 & 0.47 & 0.64 & 0.54 \\
\hline Operating profit interest coverage ratio & 3.0 & 2.4 & 2.3 & 1.4 \\
\hline EBITDA interest coverage ratio & 6.3 & 5.6 & 4.8 & 3.4 \\
\hline Debt load ratio & 2.0 & 2.0 & 2.6 & 2.5 \\
\hline Financial leverage & 1.9 & 1.6 & 4.7 & 3.6 \\
\hline Debt capital turnover ratio & 1.34 & 1.21 & 1.02 & 0.93 \\
\hline Return on borrowed capital, \% & 10.8 & 2.0 & 10.0 & 2.2 \\
\hline Economic return on assets, \% & 12.4 & 10.3 & 11.5 & 9.0 \\
\hline Weighted average cost of borrowed capital, \% & 8.3 & 8.4 & 8.3 & 9.7 \\
\hline The effect of financial leverage, \% & 6.2 & 2.5 & 11.8 & -1.9 \\
\hline Return on equity, \% & 16.1 & 10.8 & 21.0 & 5.3 \\
\hline
\end{tabular}

The increase in the debt burden of PJSC "MegaFon" is due to the growth of borrowed funds, despite the increase in EBITDA. It should be noted that an adequate level of debt burden should be no more than two. Accordingly, a value greater than two means that PJSC "MegaFon" is heavily credited, therefore, has a low credit rating, which leads to unfavorable credit conditions.

Thus, the analysis of indicators that characterize the effectiveness of leveraging PJSC "MegaFon" showed that the attraction of borrowed funds to finance corporate needs, as well as to finance the repurchase of ordinary shares in 2018-2019 led to an increase in the debt burden, a decrease in the credit rating and return on equity.

\section{Conclusions}

Based on the conducted research, we can offer the following recommendations for improving the efficiency of the use of borrowed funds of PJSC "MegaFon":

- To achieve cost savings, increasing profits and profitability.
- To attract borrowed funds with a positive effect of financial leverage.

- To attract borrowed funds only for corporate purposes, namely, for the development of the company. Thus, the effective leverage will give the opportunity to PJSC "MegaFon" to flourish and to increase the competitiveness.

\section{References}

1. I.A. Kiseleva, M.S. Gasparian, E.N. Chernysheva, T.N. Voronkova, I.S. Androshina, Int. J. of Rec. Tech. and Eng. 8, 6304 (2019)

2. L.D. Zubkova, S.M. D'yachkov, Stud. on Rus. Ec. Dev. 29, 182 (2018)

3. M. Pendar, H. Tayar, S. Karimeh, MSL. 9, 133 (2019)

4. Y. Yuniningsih, T.K. Pertiwi, E. Purwanto, MLS. 9, 205 (2019)

5. M.D.R. Vega Zavala, R.J. Santillán Salgado, Contaduría y administración 64, 1 (2019)

6. S. Dakua, Int. J. of Fin. and Ec. 24, 427 (2019) 
7. A.A. Boyko, V.V. Kukartsev, V.S. Tynchenko, V.A. Kukartsev, E.A. Chzhan, A.S. Mikhalev, Jour. of Phys.: Conf. Ser. 1333, 032009 (2019)

8. A.H. Zadorozhaya, Fin. An.: Sci. and exp. 36, 81 (2015)

9. T.A. Martynova, D.V. Eremeev, I.O. Knyazeva, Fun. Res. 11, 100 (2019)

10. Boyko, A. A., Kukartsev, V. V., Tynchenko, V. S., Eremeev, D. V., Kukartsev, A. V., \& Tynchenko, S. V. Journal of Physics: Conference Series 1353 (1), 012138 (2019)

11. D.A. Nikitin, N. Cau. reg. Ser.: Soc. Sci. 2, 319 (2017)

12. G.A. Romitsyna, N.N. Romanovskaya, Izvestiya TulGU. Ec. and legal sci. 3, 181 (2015)

13. A. A. Boyko, et al. Journal of Physics: Conference Series. 1353 (1), (2019).

14. I.V. Solntsev, Ec. and Soc. Ch.: F., Tr., For. 6, 139 (2012) 